\title{
JAMBU DRYING WITH COLD AIR CIRCULATION
}

\section{SECAGEM DE JAMBU COM CIRCULAÇÃO DE AR FRIO}

\author{
Alan Franco BARBOSA ${ }^{[1, *]}$, Tatiana Valesca Rodriguez ALICIEO ${ }^{[2]}$, Fernando Morais RODRIGUES ${ }^{[3]}$, Liliane \\ Garcia da Silva Morais RODRIGUES ${ }^{[3]}$, Armando Ubirajara Oliveira SABAA-SRUR ${ }^{[4]}$ \\ ${ }^{[1]}$ Federal Rural University of Rio de Janeiro (UFRRJ), BR 465 Km 07.Seropédica-RJ, CEP 23890-000, Brazil. \\ ${ }^{[2]}$ Federal University of Pelotas (UFPel), University campus Capão do Leão-RS, - Cx: 354, CEP 96010-900, Brazil.tatianavra@hotmail.com \\ ${ }^{[3]}$ Federal Institute of Tocantins (IFTO), Campus Paraíso do Tocantins, Rod BR 153, km 480, Distrito Industrial. Paraíso do Tocantins-TO, CEP $77600-$ \\ 000, Brazil. fernandomorais@ifto.edu.br; lilianegarcia@ifto.edu.br \\ ${ }^{[4]}$ Federal University of Rio de Janeiro (UFRJ), Department of Nutrition Basic and Experimental.373 Ave. Carlos Chagas Filho, University city. Rio de \\ Janeiro-RJ, CEP 21941-902, Brazil. sabaasrur@gmail.com
}

*Corresponding author: alanfbarbosa@yahoo.com.br

\begin{tabular}{|c|c|}
\hline ARTICLE INF. & ABSTRACT \\
\hline Received: 04/01/2015 & $\begin{array}{l}\text { The purpose of this study was to evaluate the drying process of jambu using cold air which is } \\
\text { a technology that can add value to the horticultural food, improve the production rates and }\end{array}$ \\
\hline Accepted: 05/05/2015 & help in waste reduction. Initially, the vegetable is washed in water in order to remove residual \\
\hline Published: 06/05/2015 & impurities. Then, the roots are removed. The raw material is sanitized with $200 \mathrm{ppm}\left(\mathrm{mg} \cdot \mathrm{L}^{-1}\right)$ \\
\hline Document Object Identifier & $\begin{array}{l}\text { of sodium hypochlorite ( } 10 \text { minutes). Therefore, the final rinse is carried out with a } 5 \mathrm{ppm} \\
\text { sodium hypochlorite bath for } 10 \text { minutes with the subsequent drainage of this water. The }\end{array}$ \\
\hline $10.18067 / \mathrm{jbfs} . v 2 \mathrm{i} 2.28$ & $\begin{array}{l}\text { cold air-drying of jambu is performed under temperatures around } 77^{\circ} \mathrm{F} \text { using an air } \\
\text { conditioning system. A dehumidifier is used in order to reduce the product's relative humidity }\end{array}$ \\
\hline Editor: V. H. G. Sales & $(54.6 \pm 2.87)$. The process takes place in a room with an area of 4 square meters that remains \\
\hline jbfs@ifap.edu.br & $\begin{array}{l}\text { shut during the process, which lasts a total time of } 44 \text { hours. Later, the product is stored in a } \\
\text { high protective package to avoid moisture. Jambu centrifugation is not performed because }\end{array}$ \\
\hline ID JBFS0282015 & $\begin{array}{l}\text { its leaves are fragile. The cold air-dried jambu is in accordance with the current legislation } \\
\text { regarding microbiological aspects. Also, it is well accepted by consumers and its centesimal }\end{array}$ \\
\hline Prot. $0282015 E D 01$ & composition is similar to fresh jambu. Other drying techniques can also be applied, such as \\
\hline Copyright: @ 2015 & $\begin{array}{l}\text { hot air and ultrasound. Thus, considering sanitary and sensory aspects and chemical } \\
\text { composition, the commercialization of dried jambu is feasible in terms of transport and } \\
\text { handling. }\end{array}$ \\
\hline
\end{tabular}

Keywords: Spilanthes oleracea L., vegetable, postharvest, Spilanthol

RESUMO - A proposta do trabalho foi de avaliar a secagem de jambu com ar frio, tecnologia possível de agregar valor aos hortifrutícolas com maior aproveitamento da produção e redução das perdas. Inicialmente a hortaliça é lavada para retirada de

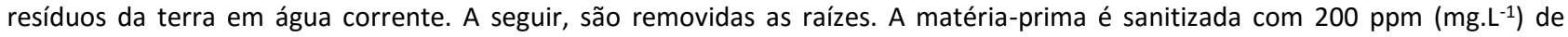
hipoclorito de sódio (10 minutos). Em seguida é realizado o enxágue final com 5 ppm de hipoclorito de sódio, durante 10 minutos com posterior drenagem dessa água. A secagem do jambu com ar frio é realizada com auxílio de ar condicionado a 25 드 e um desumidificador de ambiente para reduzir a sua Umidade Relativa $(54,6 \pm 2,87)$, numa sala de $4 \mathrm{~m}^{2}$ de área que permanece fechada durante o processo, com tempo total de 44 horas. Posteriormente o produto é acondicionado em embalagens com alta proteção ao vapor d'água. Não é realizada a centrifugação do jambu em função das suas folhas serem frágeis. $O$ jambu seco com ar frio atende a Legislação vigente quanto aos aspectos microbiológicos, apresenta boa aceitação pelos consumidores, além de composição centesimal similar ao jambu in natura. 0 jambu pode ser seco também por outras técnicas de secagem como ar quente e ultrassom. Desse modo, considerando os aspectos sanitários, sensoriais e composição química, torna-se viável a comercialização do jambu seco, facilitando o transporte, manuseio e diminuindo o volume dessa hortaliça.

Palavras-chave: Spilanthes oleracea L.; hortaliça, pós-colheita; espilantol

Funding: The authors have no support or funding to report

Competing interests: The authors have declared that no competing interests exist.

How to refer to this document (ABNT):

BARBOSA, A. F.; ALICEO, T. V. R.; RODRIGUES, F. M.; RODRIGUES, L. G. S. M.; SABAA-SRUR, A. U. Jambu drying with cold air circulation. Journal of Bioenergy and Food Science, Macapá, v.2, n. 2, p. 46-54, abr./jun.. 2015. DOI: 10.18067/jbfs.v2i2.28

\section{INTRODUCTION}

Spilanthes oleracea L., popularly known as jambu, is a plant native to the Amazon widely used as flavor in typical dishes of the Northern region of Brazil, such as the tacacá and pato no tucupi. It is also used in popular medicine for treating stomatitis, 
colds and as a painkiller. (NASCIMENTO et al., 2013). The plant has important chemical properties of interest to the pharmaceutical industry, particularly because of its active ingredient, spilanthol (BORGES et al., 2012).

Spilanthol is an amide present in the leaves, stems and inflorescence of jambu described in several patents. It is the main chemical component of the jambu. (CAVALCANTE, 2008).

Being a leafy vegetable, the jambu, has high moisture content, and, thus, post-harvest Technologies should be developed to increase shelf life of this food and meet other markets. One possible technology to be used in the conservation of this vegetable is drying, which consists in the removal of part of a portion of the free water, as steam, with consequent reduction of water activity, which impacts microbial growth, enzymatic reactions and other chemical and physical reactions. (FANG \& BHANDARI, 2011; KUROZAWA et al., 2014). Drying can increase shelf life by reducing weight and volume and lowering the costs of transportation and storage, and facilitate the use and diversify its offer. (JIN et al., 2014a).

Drying is an important method widely used in food processing (KOYUNCU et al., 2007). Due to the lack of adequate and timely processing, approximately one third of the world food production is annually lost (GUSTAVSSON et al., 2011). This loss is even greater in developing countries, where $30-40 \%$ of fruits and vegetables are wasted (KARIM \& HAWLADER, $2005 \mathrm{a}, \mathrm{b}$ ).

Cold air drying is a simplification of the lyophilization at atmospheric pressure, through the elimination of the freezing step. Water removal occurs in environments with low temperature and relative humidity, and it is kept in the liquid state during the entire process. (KUBOTA \&CAL-VIDAL, 1987).
Thus, the present study aimed to present a literature review on jambu drying using cold air circulation.

\section{Spilanthes oleracea $L$.}

This vegetable is native to tropical Brazilian regions and is grown as an ornamental and medicinal plant in several parts of the world. (LENG et al., 2011). It is widely distributed in tropical and subtropical regions, including America, Northern Australia, Africa, Malasia, Borneo, India and Sri Lanka (YADAV \& SINGH, 2010).

It belongs to the genus Spilanthes, family Asteraceae (Compositae). The genus Spilanthes contains 35 tropical species (SAVADI et al., 2010). The plant can be found in other parts of the world named as Acmella ciliata Kunth, Spilanthes acmella, Cotula pyretharia L., Spilanthes fusca MART and Bidens fervida Lan. Regarding its botanical characteristics, it is a small plant with yellow flowers, arranged in capitula. It is a perennial, semi-erect herb with decumbent branches (COSTA et al., 2013).

Popularly known as "jambu", "agrião bravo" or "agrião do Pará", its leaves and flowers cause a slight tingling and numbness in the tongue (NASCIMENTO et al., 2013). The leaves and stems are widely used in the state of Pará (Northern of Brazil) in typical recipes such as the "tacacá" and "pato no tucupi" or in rice and pizzas (COSTA et al., 2013).

The appropriate conditions of production such as preparation of the seed, transplants of the seedlings to the planting sites, irrigation, fertilization and soil coverage, as well as pest control, can be found in publications of (POLTRONIERI et al., 2000; HOMMA et al., 2011). Table 1 shows the technical and economic coefficients in jambu production (HOMMA et al., 2011).

Table 1. Technical and economic coefficients in the production of jambu considering one hectare, June 2011.

\begin{tabular}{lccc}
\hline \multicolumn{1}{c}{ Items } & Unit & Amount & Price (US\$) \\
\hline Labor & & & \\
\hline Seed & $\mathrm{lb}$ & 0.17 & 0.00 \\
Manure bird & $\mathrm{lb}$ & 154.32 & $1,115.16$ \\
Mineral fertilizer & $\mathrm{lb}$ & 220.46 & 66.38 \\
Pesticide & $\mathrm{lb}$ & 0.015 & 119.48 \\
Preparation of the area & hour & 25 & 165.94 \\
Preparation of planting sites & hour & 10 & 66.38 \\
Sowing & hour & 0.50 & 1.99 \\
Transplantation & hour & 20 & 132.75 \\
\hline
\end{tabular}

"to be continued" 
Table 1. Conclusion

\begin{tabular}{|c|c|c|c|}
\hline Items & Unit & Amount & Price (US\$ $\left.{ }^{1}\right)$ \\
\hline \multicolumn{4}{|l|}{ Labor } \\
\hline Cultural treatments & hour & 50 & 331.89 \\
\hline Harvest & hour & 25 & 165.94 \\
\hline Wash & hour & 10 & 66.38 \\
\hline Tying into bunches/packs & hour & 20 & 132.75 \\
\hline Total cost & US\$ 2,365.04 & & \\
\hline Yield & 48,000 packs/ha & & \\
\hline Gross revenue & US\$ 3,982.74 /ha & & \\
\hline Net revenue & US\$1,593.09/ha & & \\
\hline Retail price & US\$ 0.08/pack & & \\
\hline Production cost & US\$ 0.05/pack & & \\
\hline Net income (pack) & US\$ 0.03/Pack & & \\
\hline
\end{tabular}

For the calculation of the operating cost of jambu planting an area of one hectare was considered as follows: standard areas measuring 20 $\mathrm{m} \times 25 \mathrm{~m}\left(30 \mathrm{~m}^{2}\right)$, totaling 192 planting sites, with $5760 \mathrm{~m}^{2}$ of floor area. The space between each site would be $0.80 \mathrm{~m}$, and the main rows would have a length of 2 meters at each interval of 25 meters, both vertically and horizontally. An average yield of 250 packs of jambu per planting site was adopted, totaling 48,000 packs, considering a productive cycle of 2 to 2.5 months, using crop rotation (HOMMA et al., 2011).

The average production of a planting site measuring $25 \mathrm{~m} \times 1.20 \mathrm{~m}$ is 250 packs of jambu, and depending on soil fertility, cultural treatments and reduction of pests and diseases, it is possible to obtain up to 400 packs per planting site in the summer (POLTRONIERI et al., 2000; HOMMA et al., 2011). The time of greater intensity of jambu cultivation is in the wet season (ALBURQUERQUE, 1989). In general, jambu plants are harvested in packs (bundles) in the growing area, transported and then washed in a tank near the producer's house. The same water is reused several times for daily wash and disposed only on the subsequent day. This wash is the focus of contamination of the vegetables (BORGES, 2009). According to the producers, the size of these packs is a requirement of intermediate sellers. In 2011 they were sold to middlemen at US\$ 0.08 to US\$ 0.1/pack (HOMMA et al., 2011). In supermarkets and fairs they are sold in smaller packs, and in festivities their prices reach US\$ 0.33 to US\$ 0.49 /pack because of their use in typical recipes (GUSMÃO et al., 2005).

The jambu is an important source of income for small producers in the cities of Pará because the plant has multiple uses: in medicine, in food as a condiment and in ornamentation, gathering the essential elements for the establishment of a sustainable system (GUSMÃO et al., 2005).

\section{Chemical composition of the plant}

There is a growing interest in the use of vegetable and phytochemical materials throughout the world, which is associated to the search for a sustainable lifestyle. The substances extracted from the plants must have low toxicity and high degree of biodegradation (PITASAWAT et al., 1998; CHOOCHOTE et al., 1999). Therefore, phytochemicals extracted from plants have been used in nutraceutical products, pharmaceutical products, herbal medicines, spices, insect repellents, cosmetics, perfumes, among other purposes (RAMLAN \& MOHAMAD, 2000).

S. oleracea $\mathrm{L}$. is one of the most important medicinal plants, being a rich source of therapeutical compounds. (PRACHAYASITTIKUL et al., 2013). Phytochemically, the flowers, leaves and stems of $S$. oleraceaL. reportedly contain aminoacids, alkaloids (PIERIS et al., 2001), phenolic compounds, coumarin, triterpenoids (PRACHAYASITTIKUL et al., 2009) and $\mathrm{N}$-isobutylamides ( $\mathrm{N}$-isobutyl-2E,6Z,8Edecatrienamide - spilanthol, and(2E)- $\mathrm{N}$-isobutyl-2undecene-8,10-dienamide) (RAMSEWAK et al., 1999).

The $\mathrm{N}$-alkylamides, a natural group of secondary metabolites found in different genera of plants (Echinacea, Zanthoxylum, Heliopsis andSpilanthes), are new and promising bioactive molecules (BOONEN et al., 2010a). The principle or metabolite that is considered more active in SpilanthesoleraceaL. is an antiseptic amide, acid $2 E$, 6Z, 8E-deca-2,6,8 trienoic (spilanthol) (Figure 1). 
Spilanthol is the most mordant component found in the SpilanthesoleraceaL. (LENG et al., 2011).

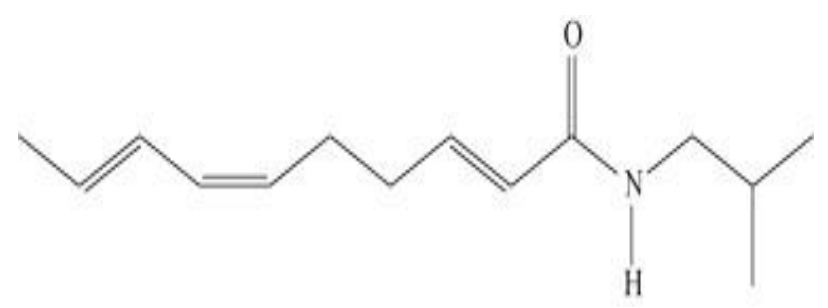

Figure 1 - Spilanthol structure. Source: (BOONEN et al., 2010b).

\section{Biological activities}

Besides its wide use in cooking, the jambu can be used for medicinal purposes because of it active principles such as saponins, spilanthines, affinins, phylosterins, cholines, triterpenoids and, particularly, spilanthol. In addition to these properties, the plant is also used as raw material in anti-wrinkle cosmetics (MARTINS et al., 2012). The main phytochemicals present in the genus Spilanthes are saturated and unsaturated ketones, alkamides, hydrocarbons, acetylenes, lactones, alkaloids, terpenes, flavonoids and coumarins. They are the main constituents responsible for the pharmacological activity (RADUNER et al., 2006). Due to the spilanthol amide, the jambu is widely used in pharmaceutical products, foods and health and body care products (PANDEY \&AGRAWAL, 2009; SINGH \& CHATURVEDI, 2012).

$S$. oleracea $\mathrm{L}$. has been widely used in the traditional Indian medicine for the treatment of several sexual dysfunctions and is used to improve the sexual functions in men. (WONGSAWATKUL et al., 2008). (SHARMA et al., 2011) report that the ethanol extract of flowers of $S$. oleracea $\mathrm{L}$. is a potent stimulator of sexual behavior in male rats, having aphrodisiac properties.

Other ethnopharmacological benefits associated to the jambu include its use in the treatment of rheumatism, inflammations, as a stimulant against stuttering, tongue paralysis, stomatitis, toothache, and headache and in the treatment of asthma, fever, sore throat, hemorrhoids and gum infections. Moreover, the extract is traditionally added to the nutritional and cosmetic supplement to accelerate the process of recovery of skin damaged by vasoconstriction (BOONEN et al., 2010b; PRACHAYASITTIKUL et al., 2013). Pharmacologically, S. oleracea $L$. is a potential vasodilator, antioxidant (WONGSAWATKUL et al., 2008) and immunomodulator (SAVADI et al., 2010). Previous studies demonstrated diuretic, antibacterial and anti-inflammatory activity
(RATNASOORIYA et al., 2004). It was also demonstrated that spilanthol in extracts of S.oleracea L. permeates the skin and oral mucosa (BOONEN et al., 2010a,b). Recently, a polysaccharide (ramnogalacturonan) has been isolated from leaves of Acmellaoleracea, which have gastroprotective activity against ethanol-induced acute gastric lesions in rats (NASCIMENTO et al., 2013). Also, (DOLUI \& DEBNATH 2010) found that the methanol extract of leaves and flowers of Spilanthes calva have a significant repellent effect against Helopeltistheivora. A significant antiinflammatory action has also been reported for the flowers.

\section{Drying}

Hot air drying is a simple and common method for drying vegetables. (LEONID et al., 2006). The disadvantages of hot air drying include low energy efficiency and lengthy drying during the falling rate period, as well as substantial degradation of product color and nutrients (DROUZAS et al., 1999; MASKAN, 2000; LEONID et al., 2006).

During the drying of broccoli, the heat reduces the retention of glucosinolates and vitamin $\mathrm{C}$, as well as the activity of the enzyme myrosinase(JIN et al., 2014a). (VEGA-GALVEZ el al., 2009) showed that, with convective drying at the 122-194 of temperature range, less than $40 \%$ of the level of vitamin $C$ in sweet pepper was maintained. They also found that retention decreases with increasing temperature.

Another drying method is lyophilization. This is a process in which moist material is dried at subatmospheric pressure (AREVALO-PINEDO \& MURR, 2006). Lyophilization has some different characteristics compared to conventional air drying, e.g. there is no oxidation because the sample is not exposed to air during the drying process. Therefore, the sensory and nutritional quality of food is maintained at a relatively short drying period and at low drying temperature. (WU et al., 2007).

Cold air drying is a simplification of the lyophilization process at atmospheric pressure, through the elimination of the freezing step. Water removal occurs in environments with low temperature and relative humidity, and it is kept in the liquid state during the entire process, so that products with intermediate moisture content can be obtained. This characteristic confers high stability to them without loss of plasticity. (KUBOTA e CALVIDAL, 1987).

The moisture retention capacity of cold air is very limited compared to that of hot air. 
Nevertheless, when relative humidity reaches sufficiently low levels, this cold air is able to absorb moisture. (HALLOWELL, 1980).

There are few studies on cold drying of food. (BARBOSA et al.2014 a,b) examined the impact of cold drying of jambu on chemical, microbiological and sensory qualities of the product. Drying was performed at a temperature of 77 ㅇ $F(77.86 \pm 1.29)$, using air conditioning and environment dehumidifier to reduce its Relative Humidity (54.6 \pm 2.87), in a room with an area of $4 \mathrm{~m}^{2}$ that remained closed during the drying procedures for 44 hours.
The author concluded that the dried jambu has a centesimal composition similar to that of fresh jambu. Moreover, dried jambu complies with the current legislation regarding microbiological aspects. Tacacá with fresh and dried jambu is well accepted by the consumers. Thus, considering health and sensory aspects and the chemical composition, the commercialization of dried jambu is feasible. The Figure $\mathbf{2}$ shows drying curve of jambu using cold air and Figure 3 shows the drying curve of jambu at a temperature of 113 ㅇ $F$

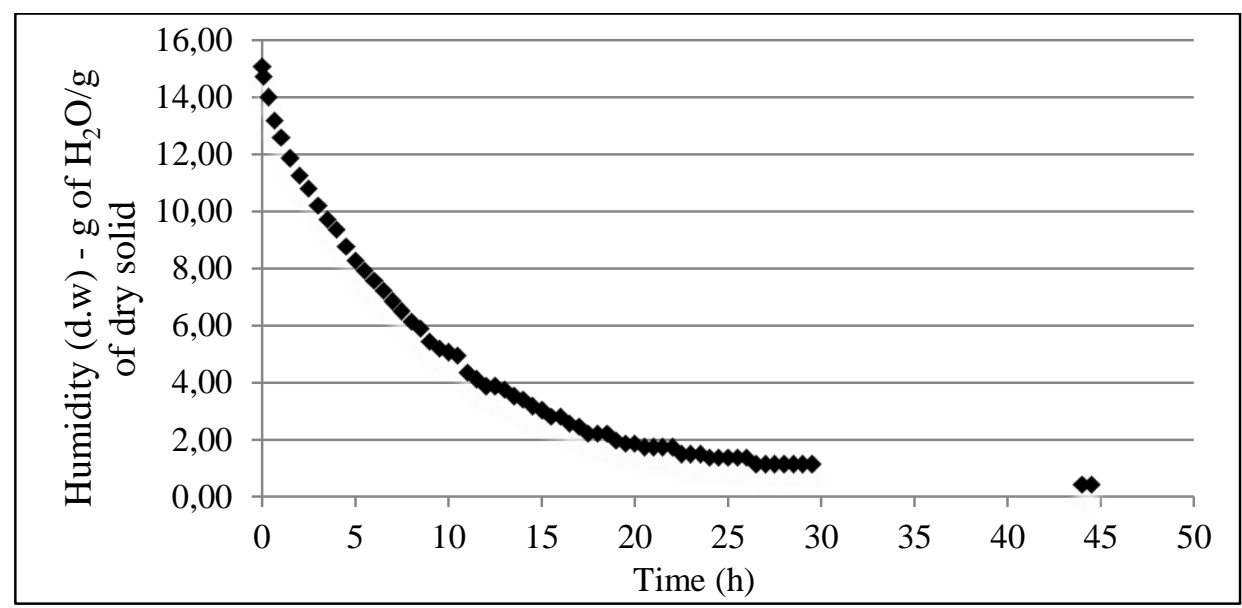

Figure 2 - Drying curve of jambu using cold air. Source: (BARBOSA et al., 2014b).

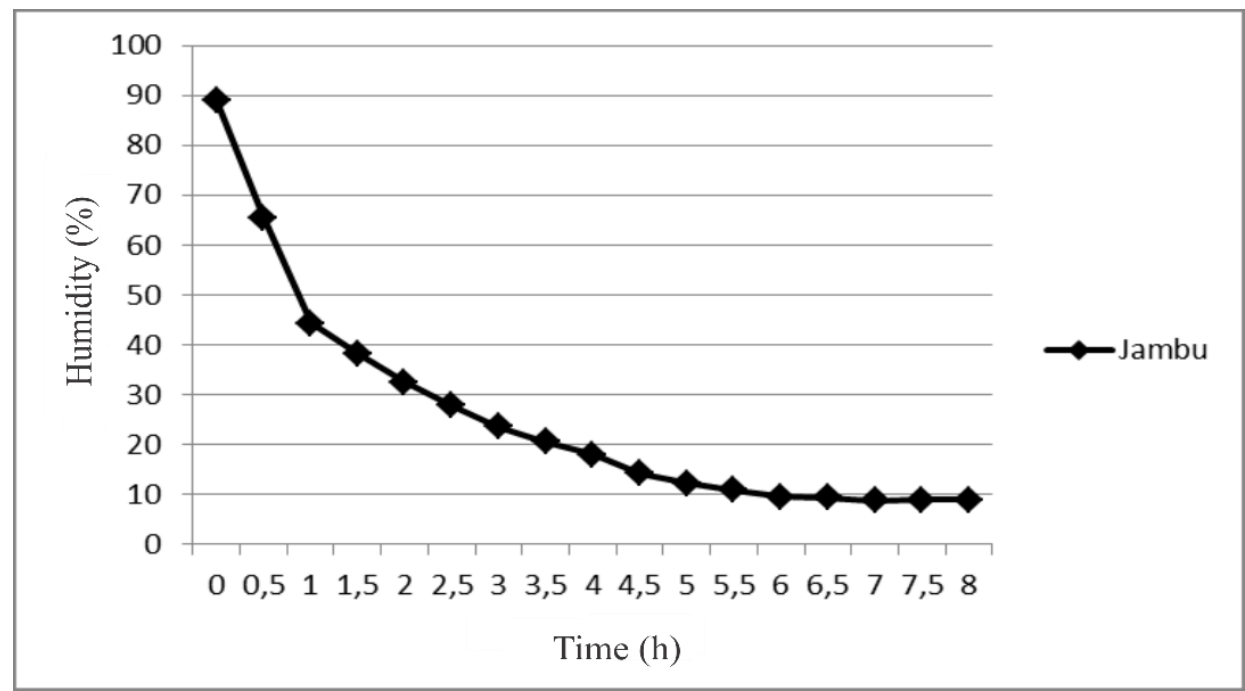

Figure 3 -. Drying curve of jambu using hot air. Source: (OLIVEIRA, 2014).

It can be seen that hot air drying is much faster than cold air drying. However, cold drying preserves the nutritional and sensory characteristics of the product.

Vieira \& Cal-Vidal (1995) investigated the effect of several operating variables on cold drying of avocado cream. In the present study, drying was performedwith a tunnel dryer, at temperatures of
$41,50,59$ and 68 of and relative humidity levels of $10,18,30$ and $40 \%$. The decrease in drying rate with increasing relative humidity was observed in all the samples. The final moisture content after a 30-hour drying period ranged from $18 \%$ (UR=10\%) to $52 \%$ (UR=40\%).

Kilic (2009) assessed the characteristics of cold drying and its effects on the quality of fish. The 
drying temperatures used in the study were $39.2,50$, 59 and $68 \stackrel{\circ}{\circ}$, the speed was $7 \mathrm{~m} / \mathrm{s}$ and the relative humidity was $40-50 \%$. The author concluded that the drying process maintains the high quality of the fish. In jambu drying, the vegetable must first be washedto remove soil residues under running water. Then, the roots are removed with stainless steel knives, and the parts of the plant that are torn, shriveled and darkened at the ends are removed. The raw material is sanitized by immersion for 10 minutes in solution with $200 \mathrm{ppm}\left(\mathrm{mg}^{-\mathrm{L}^{-1}}\right)$ of Free Residual Chlorine (FRC). Then, final rinsing is performed with immersion in solution of $5 \mathrm{ppm}$ (mg. $\mathrm{L}^{-1}$ ) of FRC, during 10 minutes, with subsequent drainage of water. Jambu centrifugation is not recommended because its leaves are fragile. The cold drying process can be carried out in an airconditioned room at 77 o $F$ and using dehumifier or equipment (e.g. tunnel dryer).

A large number of fruits and vegetables are produced in tropical and subtropical countries, and they are very attractive from a commercial point of view. However, because of seasonality, most of these products have a higher water content, which makes them susceptible to decomposition by microorganisms and chemical and enzymatic reactions. These fresh products are highly perishable and difficult to market in the fresh form in the country, as well as to be exported. (KUROZAWA et al., 2014).

Therefore, fruit and vegetable processing is essential to increase their shelf life and prevent post-harvest losses. Among the various methods used for preservation, drying is a process in which water activity is lowered by vaporization and sublimation, minimizing enzymatic and microbiological reactions. (KUROZAWA et al., 2014).

Drying is traditionally defined as an operation that converts a liquid, solid or semi-solid material into a solid product with significantly lower moisture content (ERBAY \& ICIER, 2010). Convective drying is the most widely used technique for preserving foods for long periods (JIN et al., 2014b). Convective drying of food is a process in which the convective medium (usually air) heats the surface of the food. This heat produces the evaporation of water, and excess heat increases the temperature. (GARCÍA-ALVARADO et al., 2014).

Although drying may provide dehydrated products with increased shelf life (around 1 year), the quality of dry food is significantly affected by the changes that occur during processing and/or storage, and can be drastically since the beginning (origin of the raw material). So, it is important to minimize chemical changes, such as enzymatic reactions, non-enzymatic and enzymatic darkening and oxidation of lipids and pigments, to maximize the retention of nutrients during drying (KUROZAWA et al., 2014).

The drying process causes many changes in physical, sensory and nutritional properties of foods. The main challenge of the food drying industry is producing food with desirable taste, size, color and texture (AGHBASHLO et al., 2014).

These changes are of physical, chemical and/or biochemical nature. Although the physical changes appear to be more directly related to microstructural changes of a material, these microstructural changes affect other types of changes. This happens because the changes may affect the path through which heat and mass are transferred. And this path, in turn, affects the drying characteristics of a material, and, consequently, time/temperature, which are directly related to biochemical and/or chemical changes. When food containing a bioactive compound to be later extracted is dried, microstructural changes can also affect the release of this compound from the origin of the food, thus affecting the ability to extract the compound from its structure. (HIRANVARACHAT et al., 2012).

The drying conditions have significant impact on the quality attributes of the dried product. High drying temperatures reduce drying time, but may result in poor product quality, forming a film on the food surface, with consequent increased energy consumption (HO et al., 2002). On the other hand, lower drying temperatures may improve product quality, bur reduce drying rate, extending the drying period. Intermittent drying is one of the technical solutions to this problem, since it reduces the drying time and improves product quality (KOWALSKI \& PAWŁOWSKI, 2011).

In food industry, the foods are dried in their natural form or after handling. There are more than 400 types of dryers and many of them have been used commercially (ERBAY \& HEPBASLI, 2014).

The drying method can have a negative impact on quality, e.g., hot air drying showed a negative effect on the antioxidant properties of mango (DORTA et al., 2012).

\section{CONCLUSION}

Considering the benefits of drying, sanitary and sensory aspects and chemical composition reported by studies of jambu, the commercialization of dried jambu is technically feasible, facilitating the 
transport and handling of this vegetable and reducing its mass.

\section{REFERENCES}

AGHBASHLO, M.; SOLEIMANHOSSEINPOUR, S.; GHASEMI-VARNAMKHASTI, M. Computer vision technology for real-time food quality assurance during drying process. Trends in Food Science \& Technology, v.39, p.76-84. 2014.

ALBURQUERQUE, J. M. 1989. Plantas medicinais de uso popular.Brasília: ABEAS, 96p.

AREVALO-PINEDO, A.; MURR, F. E. X. Kinetics of vacuum drying of pumpkin (Cucurbita maxima): modeling with shrinkage. Journal of Food Engineering, v.76, p.562-567, 2006.

BARBOSA, A. F.; MAIA, J. G. S.; FARIA, L. J. G.; GUSMÃO, S. A. L.; SABAA-SRUR, A. U. O. Composição centesimal de jambu (SpilanthesoleraceaL.) in natura e seco. Magistra, v.26, p.1010-1013, 2014a.

BARBOSA, A. F.; MAIA, J. G. S.; FARIA, L. J. G.; GUSMÃO, S. A. L.; SABAA-SRUR, A. U. O. Secagem de jambu (SpilanthesoleraceaL.) com ar frio: avaliação da qualidade microbiológica. Magistra, v.26, p.2319- 2322, 2014b.

BOONEN, J.; BAERT, B.; BURVENICH, C.; BLONDEEL, P.; DE SAEGER, S.; DE SIELGELEER, B. LC-MS profiling of $N$ alkylamides in Spilanthesacmella extract and the transmucosalbehaviour of its main bio-activespilanthol. Journal of Pharmaceutical and Biomedical Analysis, v.53, p.243-249, 2010a.

BOONEN, J.; BAERT, B.; ROCHE, N.; BURVENICH, C.; SPIEGELEER, B. Transdermal behaviour of the $\mathrm{N}$ alkylamidespilanthol (affinin) from Spilanthesacmella (Compositae) extracts. Journal of Ethnopharmacology, v.127, p.77-84, 2010b.

BORGES, L. S. Biomassa, teores de nutrientes, espilantol e atividade antioxidante em plantas de Jambu (Acmellaciliata Kunth) sob adubação mineral e orgânica. 108f. Dissertação (Mestrado em Agronomia/Horticultura) - Programa de Pós-graduação em Agronomia/Horticultura, Universidade Estadual Paulista "Júlio de Mesquita Filho". 2009.

BORGES, L. S.; VIEIRA, M. A. R.; MARQUES, M. O. M.; VIANELLO, F.; LIMA, G. P. P. Influence of Organic and Mineral Soil Fertilization on Essential Oil of Spilanthes oleracea cv. Jambuarana. American Journal of PlantPhysiology, v.7, p.135-142, 2012.

CAVALCANTI, V. M. S. Extração de espilantol de Spilanthesacmellavar. oleraceacom dióxido de carbono supercítico. 165f. Tese (Doutorado em Engenharia Química) - Programa de Pós-graduação em Engenharia Química, Universidade Estadual de Campinas. 2008.

CHOOCHOTE, W.; KANJANAPOTHI, D.; PANTHONG, A.; TAESOTIKUL, T.; JITPAKDI, A.; CHAITHONG, U.;
PITASAWAT, B. Larvicidal, adulticidal and repellent effects of Kaempferiagalanga. The Southeast Asian journal of tropical medicine and public health, v.30, p.470-476, 1999.

COSTA, S. S.; ARUMUGAM, D.; GARIEPY, Y.; ROCHA, S. C. S.; RAGHAVAN, V. Spilanthol Extraction Using Microwave: Calibration Curve for Gas Chromatography. Chemical Engineering Transactions, v.32, p.1783-1788, 2013.

DOLUI, A. K., DEBNATH, M. Antifeedant activity of plant extracts to an insect Helopeltistheivora. Journal of Environmental Biology, v.31, p.557-559, 2010.

DORTA, E.; LOBO, M. G.; GONZALEZ, M. Reutilization of mango byproducts: study of the effect of extraction solvent and temperature on their antioxidant properties. Journal of Food Science, v.71, p.80-88, 2012.

DROUZAS, A. E.; TSAMI, E.; SARAVACOS, G. D. Microwave/vacuum drying of model fruit gels. Journal of Food Engineering, v.39, p.117-122, 1999.

ERBAY, Z.; HEPBASLI, A. Application of conventional and advanced exergy analyses to evaluate the performance of a ground-source heat pump (GSHP) dryer used in food drying. Energy Conversion and Management, v.78, p.499-507, 2014.

ERBAY, Z.; ICIER, F. A review of thin layer drying of foods: theory, modeling and experimental results. Critical Reviews in Food Science and Nutrition, v.50, p.441-64, 2010.

FANG, Z.; BHANDARI, B. Effect of spray drying and storage on the stability of bayberry polyphenols. Food Chemistry, v.129, p.1139-1147, 2011.

GARCÍA-ALVARADO, M. A.; PACHECO-AGUIRRE, F. M.; RUIZ-LÓPEZ, I. I. Analytical solution of simultaneous heat and mass transfer equations during food drying. Journal of Food Engineering, v.142, p.39-45, 2014.

GUSMÃO, S. A. L.; GUSMÃO, M. T. A.; SILVESTRE, W. V. D.; LOPES, P. R. A. Caracterização do cultivo de jambu nas áreas produtoras que abastecem a grande Belém. Horticultura Brasileira, v.23, 2005.

GUSTAVSSON, J.; CEDERBERG, C.; SONESSON, U. Global Food Losses and Food Waste. Food and Agriculture Organization of the United Nations, 2011.

HALLOWEL, E. R. Cold and Freezer Storage Manual. 2 ed., AVI: Westport, 356p. 1980.

HIRANVARACHAT, B.; DEVAHASTIN, S.; CHIEWCHAN, N. In vitro bioaccessibility of b-carotene in dried carrots pretreated by different methods. International Journal of Food Science and Technology, v.47, p.535-541, 2012.

HO, J. C.; CHOU, S. K.; CHUA, K. J.; MUJUMDAR, A. S.; HAWLADER, M.N.A. Analytical study of cyclic temperature drying: effect on drying kinetics and 
product quality. Journal of Food Engineering, v.51, p.6575, 2002.

HOMMA, A. K. O.; SANCHES, R. S.; MENEZES, A. J. E. A.; GUSMÃO, S. A. L. Etnocultivo do jambu para abastecimento da cidade de Belém, estado do Pará. Amazônia: Ciência \& Desenvolvimento, v.6, p.125-141, 2011.

JIN, X.; OLIVIERO, T.; VAN DER SMAN, R. G. M.; VERKERK, R.; DEKKER, M.; VAN BOXTEL, A. J. B. Impact of different drying trajectories on degradation of nutritional compounds in broccoli (Brassica oleracea var. italica). Food Science and Technology, v.59, p.189-195, 2014a.

JIN, X.; VAN DER SMAN, R. G. M.; VAN STRATEN, G.; BOOM, R. M.; VAN BOXTEL, A. J. B.. Energy efficient drying strategies to retain nutritional components in broccoli (Brassica oleracea var. italica). Journal of Food Engineering, v.123, p.172-178, 2014b.

KARIM, M. A.; HAWLADER, M. N. A. Drying characteristics of banana: theoretical modelling and experimental validation. Journal of Food Engineering, v.70, p.35-45, 2005a.

KARIM, M. A.; HAWLADER, M. N. A. Mathematical modelling and experimental investigation of tropical fruits drying. International Journal of Heat and Mass Transfer, v.48, p.4914-4925, 2005b.

KILIC, A. Low temperature and high velocity (LTHV) application in drying: Characteristics and effects on the fish quality. Journal of Food Engineering, v.91, p.173182, 2009.

KOWALSKI, S. J.; PAWŁOWSKI, A. Energy consumption and quality aspect by intermittent drying. Chemical Engineering and Processing: Process Intensification, v.50, p.384-390, 2011.

KOYUNCU, T.; TOSUN, I.; PINAR, Y. Drying characteristics and heat energy requirement of cornelian cherry fruits (Cornus mas L.). Journal of Food Engineering, v.78, p.735-739, 2007.

KUBOTA, E. H.; CAL-VIDAL, J. Secagem a frio de um produto lácteo. Revista do Instituto de Laticínios Cândido Tostes, v.253, p.35-42, 1987.

KUROZAWA, L. E.; TERNG, I.; HUBINGER, M. D.; PARK, K. J. Ascorbic acid degradation of papaya during drying: Effect of process conditions and glass transition phenomenon. Journal of Food Engineering, v.123, p.157164, 2014.

LENG, T. C.; PING, N. S.; LIM, B. P.; KENG, C. L. Detection of bioactive compounds from Spilanthesacmella L. plants and its various in vitro culture products. Journal of Medicinal Plants Research, v.5, p.371-378, 2011.

LEONID, A. B.; VLADIMIR, P. G.; ANDREW, V. B.; ALEXANDER, M. L.; VALERIY, L.; VLADIMIR, A. K. The investigation of low temperature vacuum drying processes of agricultural materials. Journal of Food Engineering, v.74, p.410-415, 2006.
MARTINS, C. P. S.; MELO, M. T. P.; HONÓRIO, I. C. G.; D'ÁVILA, V. A.; CARVALHO JÚNIOR, W. G. O. Caracterização morfológica e agronômica de acessos de jambu (SpilanthesoleraceaL.) nas condições do Norte de Minas Gerais. Revista Brasileira de PlantasMedicinais, v.14, p.410-413, 2012.

MASKAN, M. Microwave/air and Microwave finish drying of banana. Journal of Food Engineering, v.44, p.71-78, 2000.

NASCIMENTO, A. M.; SOUZA, L.M. DE; BAGGIO, C.H.; WERNER, M. F. DE P.; MARIA-FERREIRA, D.; SILVA, L.M. DA; SASSAKI, G.L.; GORIN, P.A.J.; IACOMINI, M.; CIPRIANI, T.R. Gastroprotectiveeffectandstructureof a rhamnogalacturonanfromAcmellaoleracea.

Phytochemistry, 85: 137-142. 2013.

OLIVEIRA, D. C. R.; SOARES, E. K. B.; FERNANDES, H. R.; BRASIL, L. S. N. S.. Elaboração e caracterização físicoquímica, microbiológica e sensorial de pasta de alho condimentada com jambú (SpilantesoleraceaeL.) desidratado. Scientia Plena, 10: 011501-1 - 011501-8. 2014.

PANDEY, V.; AGRAWAL, V. Efficient micropropagation protocol of Spilanthesacmella $\mathrm{L}$. possessing strong antimalarial activity. In Vitro Cellular \& Developmental Biology Plant, v.45, p.491-499, 2009.

PIERIS, K. P. P.; SILVA, G. K. J.; RATNASOORIYA, W. D. Analgesic activity of water extract of Spilanthesacmella flowers on rats. Journal of Tropical Medicinal Plants, v.2, p.201-204, 2001.

PITASAWAT, B.; CHOOCHOTE, W.; KANJANAPOTHI, D.; PANTHONG, A.; JITPAKDI, A.; CHAITHONG, U. Screening for larvicidal activity of ten carminative plants. The Southeast Asian journal of tropical medicine and public health, v.29, p.660-662, 1998.

POLTRONIERI, M. C.; MÜLLER, N. R. M.; POLTRONIERI, L. S. Recomendações para a produção de jambu: cultivar Nazaré. Belém: Embrapa Amazônia Oriental, 11, 13p. 2000.

PRACHAYASITTIKUL, S.; SUPHAPONG, S.; WORACHARTCHEEWAN, A.; LAWUNG, R.; RUCHIRAWAT, S.; PRACHAYASITTIKUL, V. Bioactive metabolites from Spilanthesacmella Murr. Molecules, v.14, p.850-867, 2009.

PRACHAYASITTIKUL, V.; PRACHAYASITTIKUL, S.; RUCHIRAWAT, S.; PRACHAYASITTIKUL, V. High therapeutic potential of Spilanthesacmella: a review. EXCLI Journal, 12: 291-312. 2013.

RADUNER, S.; MAJEWSKA, A.; CHEN, JIAN-ZHONG; XIE, XIANG-QUN; HAMON,J.; FALLER, B.; ALTMANN, KARLHEINZ; GERTSCH, J.. Alkylamides from Echinacea are a new class of cannabinomimetics: cannabinoid type 2 receptor-dependent and -independent immunomodulatory effects. Journal of Biological Chemistry, v.281, p.14192-14206. 2006.

RAMLAN, A. Z.; ROJI, S. M. Processing of herbs and herbal products. Proceedings of The Seminar on 
Medicinal and Aromatic Plants - Towards Bridging Science and Herbal Industry, Kepong, Selangor, p. 1-8. 2000.

RAMSEWAK, R. S.; ERIKCSON, A. J.; NAIR, M. G. Bioactive $\mathrm{N}$-isobutylamides from the flower buds of Spilanthesacmella. Phytochemistry, v.51, p.729-732, 1999.

RATNASOORIYA, W. D.; PIERIS, K. P. P.; SAMARATUNGA, U.; JAYAKODY, J. R. A. C. Diuretic activity of Spilanthesacmella flowers in rats. Journal of Ethnopharmacology, v.91, p.317-320, 2004.

SAVADI, R.V.; YADAV, R.; YADAV, N. Study on immunomodulatory activity of ethanolic extract of Spilanthesacmella Murr. leaves. Indian Journal of Natural Products and Resources, v.1, p.204-207, 2010.

SHARMA, V.; BOONEN, J.; CHAUHAN, N. S.; THAKUR, M.; SPIEGELEER, B. D.; DIXIT, V. K. Spilanthesacmella ethanolic flower extract: LC-MS alkylamide profiling and its effects on sexual behavior in male rats. Phytomedicine, v.18, p.1161-1169, 2011.

SINGH, M.; CHATURVEDI, R. Evaluation of nutrient uptake and physical parameters on cell biomass growth and production of spilanthol in suspension cultures of SpilanthesacmellaMurr. Bioprocess andBiosystems Engineering, v.35, p.943-951, 2012.
VEGA-GALVEZ, A.; DI SCALAB, K.; RODRÍGUEZA, K.; LEMUS-MONDACAA, R.; MIRANDA, M.; LOPEZ, J.; PEREZWONA, M. Effect of air-drying temperature on physicochemical properties, antioxidant capacity, colour and total phenolic content of red pepper (Capsicum annuum, L. var. Hungarian). FoodChemistry, v.117, p.647-653, 2009.

VIEIRA, J.A.G.; CAL-VIDAL, J. Secagem a frio de creme de abacate. Pesquisa Agropecuária Brasileira, v.30, p.553$562,1995$.

WONGSAWATKUL, O.; PRACHAYASITTIKUL, S.; ISARANKURA-NA-AYUDHYA, C.; SATAYAVIVAD, J.; RUCHIRAWAT, S.; PRACHAYASITTIKU, V. Vasorelaxant and antioxidante activities of Spilanthesacmella Murr. International Journal of Molecular Sciences, v.9: p.27242744, 2008.

WU, L.; ORIKASA, T.; OGAWA, Y.; TAGAWA, A. Vacuum drying characteristics of eggplants. Journal of Food Engineering, v.83, p.422-429, 2007.

YADAV, K.; SINGH, N. Micropropagation of Spilanthesacmella Murr. - An Important Medicinal Plant. Nature and Science, v.8, p.5-11, 2010. 